\title{
The pathogenesis of cytokines in preportal fibrosis of human infected with schistosomiasis and viral hepatitis
}

\author{
Abdel Atty M. Elgonimy*, Suzan M.Farouk**, Eman Abdel Rahman*** \\ Department of Surgery*, Clinical Pathology**, Benha Teaching Hospital, Department \\ of Internal Medicine***, Faculty of Medicine for Girls, Al- Azhar university
}

\begin{abstract}
Cytokines are polypeptides exhibiting a variety of biological activities including metabolic, inflammatory, hematopoietic and immunologic properties. They play an important role in the pathogenesis of various diseases.

Inflammation is commonly observed in liver diseases and is frequently complicated by fibrosis and cirrhosis in end-stage disease. The only curative treatment for cirrhotic patients is liver transplantation.

Cytokines play a key role in the regulation of immune responses. In viral hepatitis the production of inappropriate cytokine level appears to contribute to viral persistence and to affect response to therapy. The aim of this study is to investigate the level of endogenous IL-1B, IL-6 and IL-10 to determine their relation with liver fibrosis. Forty patients with chronic liver disease and 10 normal adults as control group were studied.

Patients in this study were classified into four groups according to etiology of chronic liver disease: Group I (10 patients with bilharzial liver disease),Group II (10 patients with chronic hepatitisC), Group III(10 patients with chronic hepatitisB )and Group IV (10 patients with chronic hepatitis B and C) .

All patients with chronic liver disease $(n=40)$ showed highly significant elevation of serum IL-1B, IL-6, IL-10 mean \pm SD were $(106.4 \pm 47.8)(\mathrm{P}<0.01)(26.3 \pm 11.1)(\mathrm{P}<0.01)(135.4 \pm 73.9)$ $(\mathrm{P}<0.01)$ respectively when compared to control group. After classifying the patients into 4 groups each group showed highly significant elevation of serum IL-1B, serum IL-6 and serum IL-10 in each group when compared to control group $(p<5051)$.

Regression analysis showed negative significant correlation between serum IL-10 and IL$1 \mathrm{~B}(\mathrm{r}=-0.64, \mathrm{P}<0.05)$, highly negative significant correlation between IL-10 and IL-6 $(\mathrm{r}=-0.72$, $\mathrm{P}<0.01$ ) in all patients with chronic liver diseases, also there was highly significant positive correlation between serum IL-1B and serum IL-6 ( $r=0.83, \mathrm{P}<0.01)$.

Ten patients with bilharzial liver disease (group I) showed highly negative significant correlation between serum IL-10 and each of serum IL-1B and serum IL-6 ( $r=-0.9, P<0.01) \quad(r=-$ $0.8, \mathrm{P}<0.01)$ respectively, and there was highly significant positive correlation between serum IL-1B and serum IL-6 $(\mathrm{r}=0.96, \mathrm{P}<0.01)$. There was significant correlation between prothrombin concentration and each of serum IL-10, serum IL-1B and IL-6 $(r=0.7, P<0.05), \quad(r=0.68$, $\mathrm{P}<0.05),(\mathrm{r}=0.74, \mathrm{P}<0.05)$ respectively.

Ten patients with chronic hepatitis $\mathrm{C}$ virus (group II) also showed highly negative significant correlation between serum IL-10 and each of serum IL-1B and serum IL-6 ( $r=-0.9$, $\mathrm{P}<0.01)(\mathrm{r}=-0.9, \mathrm{P}<0.01)$ respectively. There was highly significant positive correlation between serum IL-1B and serum IL-6 $(r=0.83, P<0.01)$ and significant correlation between serum IL-1B and serum ALT $(r=0.63, \mathrm{P}<0.05)$.

As regard (group III) patients with chronic hepatitis B virus there was negative significant correlation between serum IL-10 and IL-1B $(r=-0.63, \mathrm{P}<0.05)$, but no significant correlation between serum IL-10 and serum IL- 6 and there was highly positive correlation between serum IL-1B and serum IL-6 $(r=0.90, P<0.01)$.
\end{abstract}


Ten patients with chronic hepatitis $\mathrm{C} \& \mathrm{~B}$ virus (group VI) showed highly negative significant correlation between serum IL-10 and each of serum IL-1B and serum IL-6 ( $r=-0.82$, $\mathrm{P}<0.01) \quad(\mathrm{r}=-0.80, \mathrm{P}<0.01)$ respectively. There was highly significant positive correlation between serum IL-1B and serum IL- $6(\mathrm{r}=0.88, \mathrm{P}<0.01)$ and significant correlation between serum IL-1B and serum ALT $(r=0.63, \mathrm{P}<0.05)$, and prothrombin concentration $(r=0.67, \mathrm{P}<0.05)$.

A significant correlation between the level of serum IL-1B, IL-6, and serum IL-10 and degree of fibrosis was found. The increase in serum level of IL-1B, IL-6 was associated with increase the degree of fibrosis but the mild and moderate fibrosis were associated with higher level of IL-10 while patients with marked degree of fibrosis were associated with lower level of IL-10.

\section{Introduction}

Hepatic fibrosis is a common outcome of chronic liver injury from persistent viral and helminthes infections, alcoholic liver disease, and a multitude of other causative agents.It is characterized by an increase in extra cellular matrix deposition, including type I and III collagen, proteoglycans, fibronectin and hyaluronic acid.A cirrhotic liver may contain several fold more matrix than normal liver resulting in compromised hepatic function( Davis and Kresina , 1996). The liver is an important site of synthesis and the major clearing organ for various cytokines. Mononuclear phagocytes (Kupffer cells) are potent producers of proinflammatory cytokines, including tumor necrosis factor (TNF- $\alpha$ ) Interleukin1 (IL-1) and Interleukin-6 (IL-6) (Muller et al., 1989) . In addition parenchyma and fat storing cells are able to express certain cytokines. Cytokines are involved in the onset of intrahepatic immune responses to viral hepatitis and in fibrotic and cirrhotic transformation of the liver due to viral infection (Andus and Baner, 1991).

Several cytokine including tumor necrosis factor $\alpha$ and interleukin 1 and Interleukin-6 are systemically elevated among patients with chronic liver disease (Genesca et al., 1999).

The importance of hepatitis $\mathrm{C}$ virus (HCV) infection lies in its ability to cause insidious and progressive liver damage in the majority of those infected. Although the pathogenesis of hepatocellular injury in $\mathrm{HCV}$ infection is not fully understood, there is increasing evidence to suggest immunemediated mechanisms (Nelson, 2001). The inflammatory and regulatory cytokines have been implicated in both the hepatocellular damage and the perpetuation of chronic HCV infection (Nelson et al., 2003).

Liver cirrhosis is a diffuse hepatic fibrosis, and nodule formation. IL-10 is very important cytokine in hepatic fibrosis and IL-6 production in liver cirrhosis increases according to the severity of cirrhosis( Lee et al ., 2003).

Patients with chronic HCV infection have an activated T-cell response cytokine pattern, with elevated levels of serum IL-2, IL-4, IL-10, tumor necrosis factor- $\alpha$ and Interferon gamma(IFN- $\gamma$ ) (Tilg et al ., 1992) and, (Nelson et al., 1997) .

Interleukin-10 is powerful T-helper type 2( Th2) cell cytokine produced by lymphoid cells that exerts its functions by inhibiting macrophage/monocyte and T-cell lymphocyte replication and secretion of inflammatory cytokines (IL-1, TNFA, TGFB, IL-6, IL-8, and IL-12) (Shin et al.,2003).

IL-10 is a cytokine that downregulates the proinflammatory response and has modulatory effect on hepatic fibrogenesis (Nelson, 2000). In fact endogenous IL-10 reduces the intrahepatic inflammatory and limits hepatotoxicity in several model of liver injury (Arai et al., 1995) and (Nagaki et al., (1999).

Interleukin 6 plays an essential role in the regulation of immune response to chronic disease ( Park et al .,2003). IL-6 is metabolized by hepatocytes after binding to their receptors the reduction in the number of functional hepatocytes is probably responsible for the increased level of IL-6 
in liver disease (Sonne and Davidsen, 1990 ).

IL-1B proinflammatory cytokine released from monocytes and lymphocytes in response to an inflammatory stimulus. The proinflammatory interleukins play a major role in progress of chronic hepatitis. IL-1B release by monocytes in vitro was significantly reduced in both intestinal and hepatosplenic schistosomiasis(Kishihara and Hayashi, 1996).

Hepatitis B virus (HBV) infection has clinical sequelae ranging from acute selflimited hepatitis to hepatocellular carcinoma, which are not attributable to direct cytopathic effect of the virus but rather to the individual host's immune response. Cytokines low molecular weight proteins with a broad range of activity have been shown to be involved in the regulation of hepatocyte functions, as well as in the pathogenesis leading to liver damage. Tangkijvanich et al., 2000).

In schistosomiasis, chronic disease is characterized by the establishment of Th2associated immune response against eggs trapped in organ such as the liver and intestines. Hall marks of this Th2-associated immune response include up-regulation of the collagen-inducing cytokine, IL-4 and IL-13, down-regulation of the collagensuppressing cytokine IFN- $\gamma$ and development of tissue fibrosis( Cheever and G.S Yap, 1997 ).

Recently demonstrated the IL-10 is crucial for establishing polarized eggspecific Th cell responses in vivo (Hoffman et al., 2000).

\section{Aim Of The Work}

This study is to determine whether serum level IL-1B, IL-6, and IL-10 are elevated in patients with chronic hepatitis $\mathrm{B}, \mathrm{C}$ viral infection and bilharzial liver disease and their importance in the pathophsiological process in these patients.

\section{Patients And Methods}

This study included forty patients were diagnosed as having chronic liver diseases. Their age ranged from 35-63 years (25 males and 15 females). The patients were selected from suergical liver \& GIT units in Benha Teaching Hospital and ElZahraa University Hospital. As well as 10 healthy persons who were well matched as regards age and sex as control group.

Patients with autoimmune hepatitis, hepatocellular carcinoma, drug-induced hepatitis and metabolic liver disease have been excluded.

The patients were divided according to etiology of chronic liver disease into four groups:

GroupI: $(n=10)$ patients with bilharzial liver disease ( 8 males and 2 females), their age ranged (42-52years) with mean of age (48.9 \pm 3$)$. The shistosomal nature of disease was shown by a definite history of living in an endemic area, history of receiving of antibilharzial treatment and confirmed also by demonstration of ova by rectal snip biopsy for negative cases and the condition was not associated with hepatitis B and $\mathrm{C}$ infection.

GroupII: $(\mathrm{n}=10)$ patients with chronic hepatitis $\mathrm{C}$ virus infection (6 males and 4 female) their age ranged (43-62 years) with mean of age (54.5 \pm 7.7$)$. The chronic nature of HCV was documented on basis of PCR for HCV. RNA and liver biopsy and were treated with interferon.

GroupIII: $(n=10)$ patients with chronic hepatitis B virus infection (5males and 5 female) their age ranged (35-60) with mean of age $(49.6 \pm 7.3)$. The chronic nature of $\mathrm{HBV}$ was documented on basis of HBsAg for at least 6 months and by $\mathrm{HBcIgG}$ positively and $\mathrm{HBcIgM}$ negativity

Group IV: $(\mathrm{n}=10)$ patients with chronic hepatitis $\mathrm{B}$ and $\mathrm{C}$ virus co- infection (6males and 4female) their age ranged (40-63 years) with mean of age (51.5 \pm 8.2 ).

Diagnosis of cirrhosis and its degree was based on Child's classification (history, physical examination and liver function tests). In addition to direct sonographic sign (coarse hepatic echopattern, irregular liver margins and caudate lobe/ right lobe ratio >0.65) and indirect sonographic sign of portal hypertension 
(splenomegaly, increased portal vein diameter or portal collateral, esophageal varices and ascitis).

\section{All patients and control were subjected} to the following:

1. Full history taking and clinical examination with particular emphasize on the liver and spleen and the presence of edema, ascitis, history of variceal bleeding, previous operation, blood transfusion, and dental surgery.

2. Abdominal ultrasonography examination was performed in the supine, left and right lateral position

3. Laboratory investigations include :

- Complete blood picture (CBC).

- Liver function tests (serum bilirubin direct and indirect, AST, ALT, total serum protein, albumin, prothrombin time and concentration).

- Urine and stool analysis and rectal snip biopsy.

- PCR For HCV. RNA.

- Complete serological profile of C and B virus infection including the following viral markers:

a) $\mathrm{HCV}-\mathrm{Ab}$

determinatio

$\mathrm{n}$ by ELISA

provided by

Abbott

murex.

Its principle based on that the wells of microplate strips coated with a mixture of $\mathrm{HCV}$ antigen. The test samples were incubated. Virus-specific antibodies to $\mathrm{HCV}$, if present would to the solid phase antigen then rabbit antihuman IgG labeled with (HRP) was added which would bound to any solidphase ag/ab complex previously formed .Incubation with enzyme substrate would produce a color which was measured spectrophotometrically.

b) $\mathrm{HBs} \quad \mathrm{Ag}$

determinatio

$n$ by ELISA

provided By

Omega

diagnostics.

Its principle

based on that

monoclonal

antibodies,

specific for

the eight

known HBs

Ag subtypes

were bound

to the

surface of

micro

titration

walls Ben-

Ari-Z, Mor

E, Papo $O$,

Kfir $B$ and

Klein $T$,

(2003) .Test

serum were

added

followed by

anti-HbsAg

antibody

conjugated

to (HRP).If

HbsAg was

present in

the sample it

bounded to

the antibody

in the wells

and the

conjugate

bounded to

the captured

viral

antigen. On

addition of

the

substrate, a

color would

develop.

The reaction

was stopped

and

absorbance

was

measured at $450 \mathrm{~nm}$.

c) IL-6 and IL-

1B were

measured by

competitive 
enzyme

immuno-

sorbant

assay;

samples

were

examined

for the level

of them by

using a

competitive

enzyme

immuno-

sorbant

technique $3^{\text {rd }}$

generation.

Supplied

from

cytoimmune

company,

USA

(Accucyte).

d) IL-10was

measured by

competit-ive

enzyme

immuno-

sorbant

using CYT

ELISA kit

supplied

from

Cytimmune

sciences

Inc. The

assay was

based on a

sandwich

technique.

with a

monoclonal

antibody

agonist IL-

10 as the

capture

antibody

and a second

biotinylated

monoclonal

antibody as

the detection

antibody.
- Liver biopsy was done using megrim needle liver biopsy to all Sampling: 40 patients.

Ten $\mathrm{ml}$ of venous blood were collected from every patients and controls after centrifugation and separation of serum , the serum was divided into two tubes one for routine tests and second tube of serum was stored in deep freeze at $-20^{\circ} \mathrm{C}$ until the time of the assay for estimation of serum IL-1B, 6, and 10.

Statistical analysis:

Results were tabulated and statistically analyzed using a personal computer with microstate program. The value were given as mean \pm SD. Comparison of the value were performed using the unpaired student " $t$ " test and one tailed $p$ values, $p$ is considered significant when it is $<0.05$. The correlation was done by person correlation.

\section{Results}

The results were summarized, statistically analyzed as shown in the following tables and figures.

The liver function test, and biochemical data, IL-1B, IL-6, IL-10 of patients and controls are shown in (table 1). There was highly significant increase in serum level of IL-1B, IL-6, IL-10 in all patients with chronic liver disease irrespective etiology compared to control group $(\mathrm{P}<0.01)$ (table 2). There was negative significant correlation between IL-10, IL$1 \mathrm{~B}$ and IL-6 ( $\mathrm{p}<0.05$, <0.01) respectively (table 3).

There was highly significant correlation between IL-1B and IL-6 $(\mathrm{P}<0.01)$ (table 4). There was highly significant increased in IL-1B, IL-6, and IL-10 in patients with group I (patients with bilharzial liver disease), group II (patients with chronic hepatitis C), group III (patients with chronic hepatitis B) and in-group VI (patients with chronic hepatitis $\mathrm{C}$ and $\mathrm{B}$ ) in comparison to control group $(\mathrm{P}<0.01)$ (table 5$)$.

Patients with group 1 (patient with bilharzial liver disease)there was correlation between IL-10, IL-1B and IL-6 $(\mathrm{p}<0.01)$ as regard group 11( patient with chronic hepatitis $\mathrm{C}$ virus)there was signifi- 
cant correlation between IL-10 and IL-IB, IL-6 ( $p<0.01)$, Patients with group 111 (patients with chronic hepatitis B virus infection)there was negative correlation between serum IL-10and IL-IB $(\mathrm{p}<0.05)$ and no significant correlation between IL10 and IL-6 in same group .Group VI ( patient with chronic hepatitis $\mathrm{B}$ and $\mathrm{C}$ ) there was negative significant correlation between IL-10, IL-IB $(\mathrm{p}<0.01)$ and IL-6 $(\mathrm{p}<0.01)$ (table 6) .

Group 1 patients (patients with bilharzial liver disease) there was significant correlation between IL-1B, PC percentage $(p<0.05), \quad$ IL-6 $\quad(p<0.01)$ and IL-10 $(\mathrm{p}<0.01)$. As regard group 11(patients with chronic hepatitis $\mathrm{C}$ virus) there was significant correlation between IL-IB and ALT ( $p<0.05)$, IL-6 $(\mathrm{p}<0.01)$ also there was correlation between IL-IB andIL-10 $(\mathrm{p}<0.01)$. Patients with group 111 (patients with chronic hepatitis B virus infection) there was significant correlation between serum IL-IB and prothrombin time $(p<0.05)$, IL-6 $(p<0.01)$ and IL-7410 $(\mathrm{P}<0.05)$. Group VI( patient with chronic hepatitis $\mathrm{B}$ and $\mathrm{C}$ ) there was significant correlation between IL-IB and ALT ,PTT, PC\% ( $\mathrm{p}<0.05)$ and between IL-IB ,IL-6 and IL-10 (p<0.01) (table 7).

Group I patients (patients with bilharzial liver disease) there was significant correlation between IL-6 and PC\% $(\mathrm{p}<0.05)$. Group VI (patient with chronic hepatitis $\mathrm{B}$ and $\mathrm{C}$ ) there was significant correlation between IL- 6 and ALT $(\mathrm{p}<0.05)$ prothrombin time $(\mathrm{p}<0.05)$ (table 8$)$.

Significant correlation between the level of serum IL-1B , IL-6,IL-10 and degree of fibrosis, the increase in serum level of IL-1B , IL-6 was associated with increase the degree of fibrosis but mild and moderate fibrosis were associated with higher level of IL-10 while patients with marked degree of fibrosis were associated with lower level of IL-10 (9).

Table (1): Liver function test and biochemical data in patients $(n=40)$ and control group $(n=10)$

\begin{tabular}{|l|c|c|c|c|c|}
\hline & Group I & Group II & Group III & Group vI & Control \\
\hline ALT (U/L) & $31.7 \pm 15.2$ & $38.7 \pm 30.2$ & $44.5 \pm 27.6$ & $31.6 \pm 10$ & $13.3 \pm 3.3$ \\
\hline Bilirubin (Mg/dl) & $2.8 \pm 1.9$ & $1.8 \pm 1$ & $2 \pm 1.1$ & $4.4 \pm 5.7$ & $0.53 \pm 0.17$ \\
\hline S.albumin (g/L) & $2.7 \pm 0.6$ & $2.7 \pm 0.3$ & $2.3 \pm 0.5$ & $2.6 \pm 0.4$ & $4.4 \pm 0.41$ \\
\hline ALK.PH (U/L) & $177.7 \pm 46.5$ & $174.9 \pm 29.5$ & $244.8 \pm$ & $166 \pm 30.2$ & $119.1 \pm 6$ \\
\hline Prothrom-bin Time & $17.1 \pm 2.6$ & $17.4 \pm 1.7$ & $16.9 \pm 2.4$ & $16.6 \pm 1.2$ & $12.5 \pm 0.9$ \\
\hline PC\% & $42 \pm 4.3$ & $46.5 \pm 4$ & $45.2 \pm 4.7$ & $44.7 \pm 3.2$ & $88.2 \pm 4.2$ \\
\hline IL-1B (pg./ml) & $93.6 \pm 46.5$ & $99.3 \pm 48$ & $100.8 \pm 36.3$ & $132.2 \pm 55.7$ & $1.3 \pm 0.9$ \\
\hline IL-6 (ng/ml) & $26.4 \pm 8.4$ & $27.6 \pm 12.8$ & $24.5 \pm 10.3$ & $26.8 \pm 13.8$ & $0.03 \pm 0.01$ \\
\hline IL-10 (ng/ml) & $90.6 \pm 41.3$ & $145 \pm 59.4$ & $160.4 \pm 79.7$ & $145.6 \pm 94.5$ & $0.19 \pm 0.006$ \\
\hline
\end{tabular}

Group I: Patients with bilharzial liver disease

Group II: Patients with hepatitis C virus

Group III: Patients with hepatitis B virus

Group VI: Patients with hepatitis $\mathrm{C}$ and $\mathrm{B}$ virus

Table (2): The mean \pm SD of serum IL-1B, IL-6 and IL-10 in all patients group (n=40) compared with control group.

\begin{tabular}{|c|c|c|c|c|c|}
\hline & $\begin{array}{c}\text { Patients group } \\
(\mathrm{n}=40)\end{array}$ & $\begin{array}{c}\text { Control } \\
(\mathrm{n}=10)\end{array}$ & T value & P value & Significant \\
\hline IL-1B $(\mathrm{pg} . / \mathrm{ml})$ & $106.4 \pm 47.8$ & $1.3 \pm 0.9$ & 5.1 & $<0.01$ & HS \\
\hline IL-6 $(\mathrm{ng} / \mathrm{ml})$ & $26.3 \pm 11.1$ & $0.03 \pm 0.01$ & 5.7 & $<0.01$ & HS \\
\hline IL-10 $(\mathrm{ng} / \mathrm{ml})$ & $135.4 \pm 73.9$ & $0.19 \pm 0.006$ & 1.7 & $<0.01$ & HS \\
\hline
\end{tabular}

Table (3): Correlation between serum IL-10 and IL-1Band serum IL-6 in all patients group $(n=40)$ 


\begin{tabular}{|l|c|c|c|c|}
\hline & Parameter & R value & P value & Significant \\
\hline $\begin{array}{l}\text { IL-10 } \\
(\mathrm{ng} / \mathrm{ml})\end{array}$ & IL-1B $(\mathrm{pg} . / \mathrm{ml})$ & -0.64 & $<0.05$ & $\mathrm{~S}$ \\
\cline { 2 - 5 } & IL-6 $(\mathrm{ng} / \mathrm{ml})$ & -0.72 & $<0.01$ & $\mathrm{HS}$ \\
\hline
\end{tabular}

Table (4): Correlation between serum IL-1Band serum IL-6 in all patients group $(n=40)$

\begin{tabular}{|l|c|c|c|c|}
\hline & Parameter & R value & P value & Significant \\
\hline IL-1B $(\mathrm{pg} . / \mathrm{ml})$ & IL-6 $(\mathrm{ng} / \mathrm{ml})$ & 0.83 & $<0.01$ & HS \\
\hline
\end{tabular}

Table (5): Comparative study between four groups of patients (each group 10 patients) and control using student " $T$ " test

\begin{tabular}{|c|c|c|c|c|}
\hline & & $\begin{array}{c}\text { IL-1B } \\
\text { (pg./ml) }\end{array}$ & $\begin{array}{c}\text { IL-6 } \\
(\mathrm{ng} / \mathrm{ml})\end{array}$ & $\begin{array}{c}\text { IL-10 } \\
(\mathrm{ng} / \mathrm{ml})\end{array}$ \\
\hline Group I \& Control & $\begin{array}{c}\mathrm{T} \text { value } \\
\mathrm{P} \text { value } \\
\text { Significant }\end{array}$ & $\begin{array}{c}3.3 \\
<0.01 \\
\text { HS }\end{array}$ & $\begin{array}{c}4.9 \\
<0.01 \\
\text { HS } \\
\end{array}$ & $\begin{array}{c}9.1 \\
<0.01 \\
\text { HS } \\
\end{array}$ \\
\hline Group II \&Control & $\begin{array}{c}\mathrm{T} \text { value } \\
\mathrm{P} \text { value } \\
\text { Significant }\end{array}$ & $\begin{array}{c}2.3 \\
<0.01 \\
\text { HS }\end{array}$ & $\begin{array}{c}1.2 \\
<0.01 \\
\text { HS }\end{array}$ & $\begin{array}{c}2.1 \\
<0.01 \\
\mathrm{HS}\end{array}$ \\
\hline GroupIII \&Control & $\begin{array}{c}\mathrm{T} \text { value } \\
\mathrm{P} \text { value } \\
\text { Significant }\end{array}$ & $\begin{array}{c}3.8 \\
<0.01 \\
\text { HS } \\
\end{array}$ & $\begin{array}{c}3.2 \\
<0.01 \\
\text { HS }\end{array}$ & $\begin{array}{c}2.7 \\
<0.01 \\
\text { HS }\end{array}$ \\
\hline GroupIV\& Control & $\begin{array}{c}\mathrm{T} \text { value } \\
\mathrm{P} \text { value } \\
\text { Significant }\end{array}$ & $\begin{array}{c}3.5 \\
<0.01 \\
\mathrm{HS} \\
\end{array}$ & $\begin{array}{c}4.4 \\
<0.01 \\
\text { HS } \\
\end{array}$ & $\begin{array}{c}6.2 \\
<0.01 \\
\text { HS } \\
\end{array}$ \\
\hline
\end{tabular}

Table (6): Correlation between serum IL-10 and AST, ALT, prothrombin time, prothrombin concentration, IL-1B and IL-6 in each 4 group of patient

\begin{tabular}{|c|c|c|c|c|c|c|}
\hline & & & Group I & Group II & Group III & Group VI \\
\hline \multirow[t]{2}{*}{$\begin{array}{l}\text { IL-10 } \\
\text { (ng/ml) }\end{array}$} & $\begin{array}{l}\text { AST } \\
\text { U/L }\end{array}$ & $\begin{array}{l}\mathrm{R} \text { value } \\
\mathrm{P} \text { value } \\
\text { significant }\end{array}$ & $\begin{array}{l}-0.19 \\
>0.05 \\
N S\end{array}$ & $\begin{array}{l}-0.4 \\
>0.5 \\
\text { NS }\end{array}$ & $\begin{array}{l}-0.65 \\
<0.05 \\
S\end{array}$ & $\begin{array}{l}-0.29 \\
>0.05 \\
\text { NS }\end{array}$ \\
\hline & $\begin{array}{l}\text { ALT } \\
\mathrm{U} / \mathrm{L}\end{array}$ & $\begin{array}{l}\mathrm{R} \text { value } \\
\mathrm{P} \text { value } \\
\text { significant }\end{array}$ & $\begin{array}{l}0.22 \\
>0.05 \\
\text { NS }\end{array}$ & $\begin{array}{l}-0.59 \\
>0.05 \\
\text { NS }\end{array}$ & $\begin{array}{l}0.07 \\
>0.05 \\
\text { NS }\end{array}$ & $\begin{array}{l}0.59 \\
>0.05 \\
\text { NS }\end{array}$ \\
\hline
\end{tabular}




\begin{tabular}{|l|l|l|l|l|l|l|}
\hline & Prothrombin & R value & -0.26 & -0.55 & -0.31 & -0.32 \\
& Time & P value & $>0.05$ & $>0.05$ & $>0.05$ & $>0.05$ \\
& significant & NS & NS & NS & NS \\
\cline { 2 - 7 } & PC\% & R value & -0.7 & 0.16 & -0.27 & 0.49 \\
& P value & $<0.05$ & $>0.05$ & $>0.05$ & $>0.05$ \\
& significant & NS & NS & NS & NS \\
\cline { 2 - 7 } & IL-1B & R value & -0.9 & -0.9 & -0.63 & -0.82 \\
& P value & $<0.01$ & $<0.01$ & $<0.05$ & $<0.01$ \\
& significant & HS & HS & S & HS \\
\cline { 2 - 7 } & IL-6 & R value & -0.8 & -0.9 & -0.58 & -0.80 \\
& (ng/ml) & P value & $<0.01$ & $<0.01$ & $>0.5$ & $<0.01$ \\
& significant & HS & HS & NS & HS \\
\hline
\end{tabular}

Table (7): Correlation between serum IL-1B and AST, ALT, prothrombin time, prothrombin concentration, IL-10 and IL-6 in each 4 group of patient

\begin{tabular}{|c|c|c|c|c|c|c|}
\hline & & & Group I & Group II & Group III & Group VI \\
\hline \multirow[t]{6}{*}{$\begin{array}{l}\text { IL-1B } \\
\text { (pg./ml) }\end{array}$} & $\begin{array}{l}\text { AST } \\
\text { U/L }\end{array}$ & $\begin{array}{c}\mathrm{R} \text { value } \\
\mathrm{P} \text { value } \\
\text { significant }\end{array}$ & $\begin{array}{c}0.17 \\
>0.05 \\
\text { NS }\end{array}$ & $\begin{array}{c}0.18 \\
>0.05 \\
\text { NS }\end{array}$ & $\begin{array}{c}-0.05 \\
>0.05 \\
\text { NS }\end{array}$ & $\begin{array}{c}0.42 \\
>0.05 \\
\text { NS }\end{array}$ \\
\hline & $\begin{array}{l}\text { ALT } \\
\text { U/L }\end{array}$ & $\begin{array}{l}\mathrm{R} \text { value } \\
\mathrm{P} \text { value } \\
\text { significant }\end{array}$ & $\begin{array}{c}-0.29 \\
>0.05 \\
\text { NS }\end{array}$ & $\begin{array}{c}0.63 \\
<0.05 \\
S\end{array}$ & $\begin{array}{c}0.44 \\
>0.05 \\
\text { NS }\end{array}$ & $\begin{array}{c}-0.63 \\
<0.05 \\
S\end{array}$ \\
\hline & $\begin{array}{l}\text { Prothrombin } \\
\text { Time }\end{array}$ & $\begin{array}{l}\mathrm{R} \text { value } \\
\mathrm{P} \text { value } \\
\text { significant }\end{array}$ & $\begin{array}{c}0.32 \\
>0.05 \\
\text { NS }\end{array}$ & $\begin{array}{c}0.47 \\
>0.05 \\
\text { NS }\end{array}$ & $\begin{array}{c}0.63 \\
<0.05 \\
S\end{array}$ & $\begin{array}{c}0.66 \\
<0.05 \\
S\end{array}$ \\
\hline & $\mathrm{PC} \%$ & $\begin{array}{c}\mathrm{R} \text { value } \\
\mathrm{P} \text { value } \\
\text { significant }\end{array}$ & $\begin{array}{c}0.68 \\
<0.05 \\
S\end{array}$ & $\begin{array}{c}0.22 \\
>0.05 \\
\text { NS }\end{array}$ & $\begin{array}{c}-0.13 \\
>0.05 \\
\text { NS }\end{array}$ & $\begin{array}{c}-0.67 \\
<0.05 \\
S\end{array}$ \\
\hline & $\begin{array}{l}\text { IL-10 } \\
\text { (ng/ml) }\end{array}$ & $\begin{array}{c}\mathrm{R} \text { value } \\
\mathrm{P} \text { value } \\
\text { significant }\end{array}$ & $\begin{array}{c}0.92 \\
<0.01 \\
\text { HS }\end{array}$ & $\begin{array}{c}0.92 \\
<0.01 \\
\text { HS }\end{array}$ & $\begin{array}{c}0.63 \\
<0.05 \\
\mathrm{~S}\end{array}$ & $\begin{array}{c}0.81 \\
<0.01 \\
\text { HS }\end{array}$ \\
\hline & $\begin{array}{c}\text { IL-6 } \\
\text { (ng/ml) }\end{array}$ & $\begin{array}{l}\mathrm{R} \text { value } \\
\mathrm{P} \text { value } \\
\text { significant }\end{array}$ & $\begin{array}{c}0.96 \\
<0.01 \\
\text { HS }\end{array}$ & $\begin{array}{c}0.83 \\
<0.01 \\
\mathrm{HS}\end{array}$ & $\begin{array}{c}0.90 \\
<0.01 \\
\mathrm{HS}\end{array}$ & $\begin{array}{c}0.88 \\
<0.01 \\
\text { HS }\end{array}$ \\
\hline
\end{tabular}

Table (8): Correlation between serum IL-6 and AST, ALT, prothrombin time, prothrombin concentration, in each 4 group of patient

\begin{tabular}{|l|c|c|c|c|c|c|}
\hline & & & Group I & Group II & Group III & Group VI \\
\hline IL-6 & & & & & & \\
$(\mathrm{ng} / \mathrm{ml})$ & $\mathrm{AST}$ & $\mathrm{R}$ value & 0.17 & 0.51 & -0.02 & 0.42 \\
& $\mathrm{U} / \mathrm{L}$ & P value & $>0.05$ & $>0.05$ & $>0.05$ & $>0.05$ \\
& & significant & NS & NS & NS & NS \\
\cline { 2 - 7 } & ALT & R value & 0.15 & 0.55 & 0.23 & 0.68 \\
& $\mathrm{U} / \mathrm{L}$ & P value & $>0.05$ & $>0.05$ & $>0.05$ & $<0.05$ \\
& & significant & NS & NS & NS & S \\
\hline
\end{tabular}




\begin{tabular}{|c|c|c|c|c|c|c|}
\hline & Prothrombin & R value & 0.22 & 0.52 & 0.49 & 0.64 \\
& Time & P value & $>0.05$ & $>0.05$ & $>0.05$ & $<0.05$ \\
& & NS & NS & NS & S \\
\cline { 2 - 7 } & PC\% & R value & 0.74 & 0.03 & -0.12 & -0.34 \\
& & P value & $<0.05$ & $>0.05$ & $>0.05$ & $>0.05$ \\
& & significant & $\mathrm{S}$ & $\mathrm{NS}$ & $\mathrm{NS}$ & $\mathrm{NS}$ \\
\hline
\end{tabular}

Table (9): Comparison between level of serum IL-1B, IL-6, and IL-10 and degree of fibrosis

\begin{tabular}{|c|c|c|c|c|c|}
\hline Degree of fibrosis & Number & Patients & IL-1B level & IL-6 level & IL-10 level \\
\hline Minimal fibrosis & 13 & $32.5 \%$ & 63.7 & 15.6 & 207.5 \\
\hline Mild fibrosis & 7 & $17.5 \%$ & 88.8 & 21.5 & 138.2 \\
\hline Moderate fibrosis & 9 & $22.5 \%$ & 108.9 & 28.5 & 115.3 \\
\hline Marked fibrosis & 11 & $27.5 \%$ & 142.9 & 40.2 & 64.7 \\
\hline
\end{tabular}

\section{Discussion}

Cytokines play a key role in the regulation of the immune response. The maximal capacity of cytokine production varies among individuals as correlates with polymorphism in the cytokine gene promoters (Ben-Ari, et al., 2003).

An imbalance in Th1 and Th2 cytokine production is implicated in disease progression of hepatitis virus (Nelson et al., 2003). T-helper type 1 cytokines are required for host antiviral immune responses, T- helper type 2 cytokines can inhibit the development of these effectors mechanism (Abaly and Canataroglu, 2003).

In addition, an infective cytokines response is thought to be one of the reasons for the failure to suppress hepatitis virus replication and to eliminate the virus (Song et al., 2003).

Our results demonstrated there was significantly elevated of serum interleukin 1B, IL-6, IL-10 in all patients with chronic liver disease in comparison to controls. No significant difference was found when these levels were compared to etiology of chronic liver disease.

Also the results showed the level of serum IL-1B was highly significantly increase in patients with bilharzial liver disease, patients with chronic hepatitis $\mathrm{C}$, patients with chronic hepatitis $\mathrm{B}$ and in patients with chronic hepatitis $\mathrm{B}$ and $\mathrm{C}$ respectively in comparison to control group.

These results agree with Tilg $\mathrm{H}$; et al, (1992) who reported that serum levels of proinflamatory cytokines TNF- $\alpha$ IL-1B and IL-6 as well as IFN- $\gamma$ are significantly elevated in patients with chronic liver disease. They added that these changes are independent of etiology of underlying liver disease.

Low concentrations of circulating IL$\mathrm{B}$ were detected in comparable frequencies in untreated patients and control. Three months after therapy IL-1B was detectable in serum in an increased proportion of intestinal schistosomiasis patients. IL-1B release in vitro gradually increased in all patients and reached control value 6 months after therapy (Zwingenherger and Irschick, 1990). This finding not agreed with our result as we found that there was an increased IL-1B in-patient with schistosomiasis than in normal control.

In this study we have shown marked increase in the serum IL-1B and IL-6 in patients with chronic hepatitis $\mathrm{C}$ virus, there was significant correlation between serum IL-1B, and IL-6 and both elevation were associated with the degree of fibrosis in patients with chronic liver diseases.

Lapiniski, (2001) reported that the level of serum IL-1B and IL-6 in all HCV 
patients were higher in comparison with healthy adults. The patients with HCV infection demonstrated a significant correlation between serum and liver -tissue level of IL$1 \mathrm{~B}$ and the level of serum IL-6 in-patients with moderate chronic active hepatitis were higher when compared with patients with mild chronic persistent hepatitis.

Normally IL-6 is not constitutively expressed but induced in the liver by viral infection. It has also been noted that the most potent induce of IL- 6 in the Kupffer cells of rats is viruses moreover, IL-6 are directly stimulated by $\mathrm{TNF} \propto$ and IL-1 (Busan and Baur, 1990).

In agreement with our findings, several studies have shown raised serum IL-6 levels in-patients with liver cirrhosis (Genesca et al., 1999) and( Wilbur, 1993).

IL-6 levels increase with the severity of liver disease. Its production in Child's grade $\mathrm{C}$ was significantly higher compared with Child's grade A and B patients irrespective of the etiology (Genesca et al., 1999).

Also Malguarnera et al; (1996) who agree with our results showed that IL-6 serum level were significantly increased in patients with liver cirrhosis (post hepatitis) suggesting that IL- 6 stimulates and sustains liver fibrosis and that rise in IL-6 serum level is due to impaired hepatitis clearance of this cytokine, while its production remains steady.

In our study, we found also that there was highly significant elevation of serum IL-6 in-patients with chronic hepatitis B virus when compared to control group and it was highly significant correlation with serum IL-1B.

The results agree with Song, et al; (2003), Tangkijvanich, et al ; (2000) and disagree with Park et al ; (2003) who reported no significant association between IL-6 promoter variant and disease outcome in chronic hepatitis B.

Tangkijvanich, et al ; (2000) found data demonstrated a positive correlation between serum IL- 6 and clinical severity of chronic HBV infection. Therefore, IL-6 might rather be responsible for liver inflammation and regeneration in chronic liver disease.
As regard to serum level of IL-10 was significantly increased in patients with chronic hepatitis $\mathrm{C}$ virus compared to controls .These results agree with Abaly and Canataroglu ,2003) who reported that serum levels of IL-10 but not IFN- $\gamma$ were found to be significantly increased in chronic hepatitis $\mathrm{C}$ virus compared to control subjects. This may suggest the involvement of $\mathrm{Th} 2$ cytokines in the pathogenesis of chronic HCV liver disease. In addition, in the present study, significant correlation between the level of IL-10 and degree of liver fibrosis was present; the mild and moderate degrees of fibrosis were associated with higher IL-10 levels. This agrees with Cressman, et al; (1996) who reported that endogenously produced IL-10 can modulate liver fibrosis. And Louis, et al; ( 2003) reported that in acute macrophage- mediated hepatitis induced by galactosamin/ lipopolysaccharide dminis-tration, IL-10 neutralization lead to a more sever liver damage, whereas IL-10 injection, even delayed, was able to limit liver necrosis.

IL-10 has been shown to be an important component of shistosomiasis induced cross regulation. IL-10 could play a major role in the down regulation of granuloma formation as well as host cell mediated responses to established schistosoma worm infection (Sher, 1993).

\section{Conclusion}

In conclusion, we have shown serum level of IL-1B, IL-6 and IL-10 were increased in patients with chronic liver disease and this increase does not depend on the etiology of underlying liver disease. The increase of these cytokines was associated with the degree of fibrosis and this finding highlight the complexity of the host immune.

\section{References}

1- Abaly B and Canataroglu A, (2003): Serum profile of T- helper 1 and T- helper 2 cytokines in patients with chronic hepatitis $\mathrm{C}$ virus infection. Turk-J- Gastroentrol. Mar; 14:7-11. 
2- Andus T and Baner J,(1991):Effects of cytokines on the liver. Hepatology, 13:36475.

3- Arai T, Hircmolsu K, Kobayashi N and Takuno M, (1995): IL-10 is involved in the protective effect of dibutyryl cyclic adenosine monophosphate on endotoxininduced inflammatory liver disease. J Immunology; 155:5743-5749.

4- Ben-Ari-Z, Mor E, Papo O, Kfir B and Klein T, (2003): Cytokine gene polymorphism in patients infected with hepatitis B virus. An-J- Gastroentrol. Jan; 98 144-50.

5- Busam KJ and Bauer TM, (1990): Interleukin-6 released by rat liver macrophages. J. Hepatol; 191:575-582.

6- Cressman DE and Greenbaum LE, (1996): Liver failure and defective hepatocyte regeneration in IL-6 deficient mice. Science, 4:1379.

7- Cheever AW and G.S Yap, (1997): Immunology basis of disease and disease regulation in schistosomiasis. Chem. Immunology, 66:159.

8- Davis BH and Kresina TF, (1996): Hepatic fibrogenesis. Hepatitis Chronic Liver Dis, 2:361-375.

9- Genesca J, Gonzalez A, Segura R, Catalan Rand Marti R, (1999): Interleukin -6 , nitric oxide, and the clinical and hemodynamic alteration of patients with liver cirrhosis. Am j Gastroentrol; 94:169-77.

10- Hoffman KF, Cheever AW, and Wynn TA, (2000): IL-10 and the dangers of immune polarization: Excessive type one and type 2 cytokine responses induce distinct forms of lethal immunopatholgy in murine shistosomiasis. The Journal of immunology, 104:6406-6416.

11- Kishihara Y and Hayashi J, (1996): IL-B and TNF- $\alpha$ produces by peripheral blood mononuclear cells before and during interferon therapy in-patients with chronic hepatitis C. Dig.Dis.Sci: Vol. 41N. 2:315-321.

12- Lapiniski TW, (2001): The level of IL-1B, IL-4, and IL-6 in the serum and the liver tissue of chronic HCV- infected patients. Arch Immunol Ther Exp). 49311-6.

13- Lee BS ,Kim NJ, Jeong HY, Lee HY, and Noh SM, (2003): Change in serum cytokine concentration: a morphological study of liver cirrhosis induced by common bile duct ligation in rats, Mar; 18, 6-12.

14- Louis H, Le-Moine O, Goldman M, and Deviere J, (2003): Modulation of liver injury by Interleukin-10.Acta. Gastroentrol. Belg. Jan-Mar, 66, 7-14.
15- Malaguarnera $M$ and Trovato BA, (1996): Interleukin-6 in hepatitis $C$ cirrhosis. Panminerva.Med.Des; 38:207-10.

16- Muller C, Godl I, Ahmed R, Wolf H, Mand, et al; (1989): Interleukin-1 production in acute viral hepatitis. Arch. Dis. Child.64: 205-210.

17- Nagaki $M$, Tanaka $M$, Mugiyama $A$, Ohnishi H, and Moriwaki H, et al; (1999): Interleukin 10 inhibits hepatic injury and tumor necrosis- $\alpha$ and interferon$\gamma$ mRNA expression induced by staphylococcal enterotoxine B or lipopolysacharide in galactosamine-sensitized mice.J Hepatol; 31:815-824.

18- Nelson D.R; (2001): The Immunopathogenesis of hepatitis $\mathrm{C}$ virus infection. In: Raymond Koff, ed. Clin. Liver Dis. and 5:931-953.

19- Nelson DR, Consuelo ZT and Gary LD, (2003): Long term Interleukin 10 Therapy in Chronic Hepatitis $\mathrm{C}$ patients has a proviral and anti-inflammatory effect.

20- Nelson DR, Lauwers GY and Davis GL, (2000): Interleukin 10 Treatment Reduces Fibrosis in patients with Chronic Hepatitis C: A Pilot Trial of Interferon Nonresponders.Gastroenterology; 118:655-660.

21- Nelson DR, Lim HL, Marousis CG, Fang JW, and Davis GL, (1997): Activation of tumor necrosis- $\alpha$ system in chronic hepatitis $C$ virus infection. Dig Dis SCI; 2:2487-2494.

22- Park BL, Lee HS, Kimy J, Jung JH, Kim LH and Shin HD, (2003): Association between interleukin-6 promoter Variants and chronic hepatitis B progression. Exp.Mol. Med. Apr; 30; 35:76-82.

23- Sher A, (1993): Immunoregulatory and immunopathogenic role of Th2 cytokines in murine schistosomiasis. Abstract on international conference on schistosomiasis,672-74.

24- Shin HD, Park BL, Kim LH, Jung JH and Lee HS, (2003): Interleukin 10 haptotype associated with increased risk of hepatocellular carcinoma. Hum-Mol-Genet, Apr; 15; 12: 901-6.

25- Song le-H, Binh VQ, Duy DN, Kun JF and Luty AJ, (2003): Serum cytokine profiles associated with clinical presentation in Vietnamese infected with hepatitis B virus. J-Clin- Immunol.31: 205.

26- Sonne O and Davidsen O, (1990): Cellular targets and receptors for interleukin-6, in: vivo and in vitro uptake of IL-6 in liver and hepatocytes. Eur. J. Clin. Invest; 20:366370. 
27- Tangkijvanich $P, \quad$ Vimolket $T$, Theamboonlers A, Kullavanijaya $P$, and Poovorawan Y, (2000): Serum interleukin6 and interferon-gamma levels in-patients with hepatitis B- associated chronic liver disease. Asian Pac J Allergy Immunol. Jun; $18: 109-14$.

28- Tilg H, Wilmer A, Vogel W, Herold M, and Huber C, (1992): Serum level of cytokine in chronic liver disease. Gastroenterology; 103:264-274.

29- Wilbur J.C, (1993): Development and use of laboratory tests for hepatitis $\mathrm{C}$ infection: a review .J.Clin Immunoassay 16:200207.9

30- Zwingenberger K.E and Irschick J.G, (1990): Tumor necrosis factors in hepatosplenic schistosomiasis. Scand. J. Immunol.31: 205.

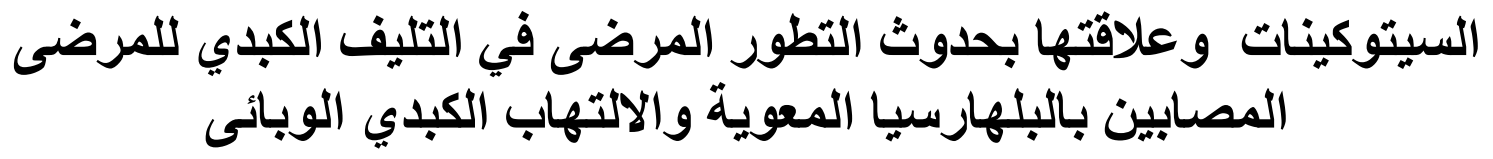

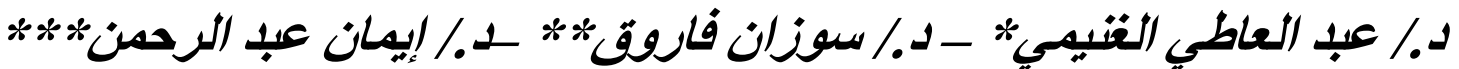

$$
\begin{aligned}
& \text { قسم الجراحةّ* و الباثّولوجيا اكينيكية***( مستشفي بنها التعليمي) وقسم الباطنة }
\end{aligned}
$$

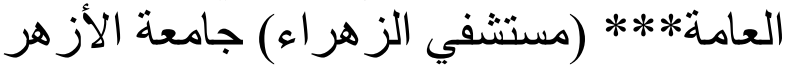


للسيتوكينات دور هام في تتظيم الاستجابة المناعية وفى حالات الالتهاب الكبدي

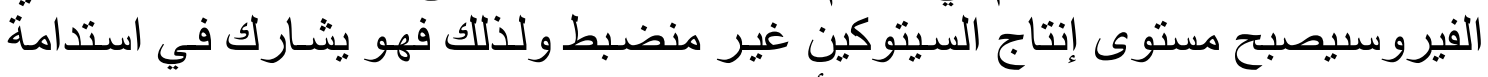

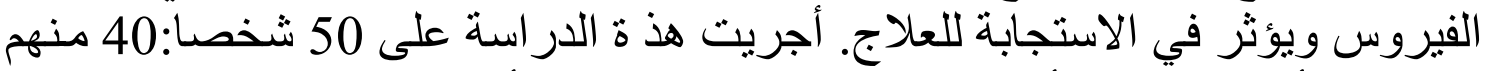

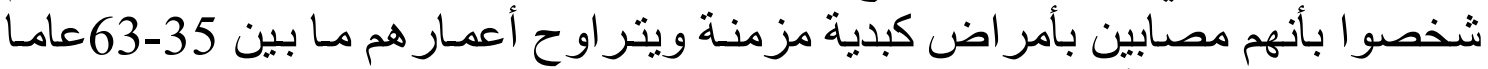

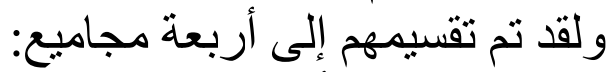

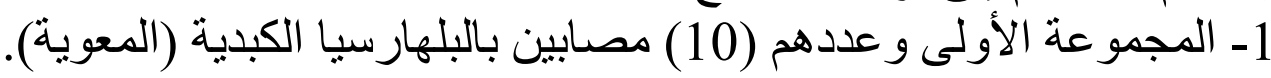

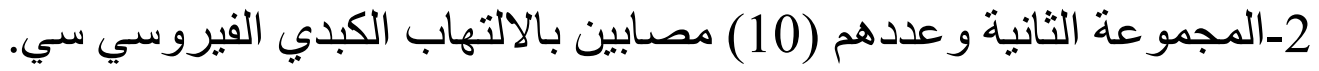

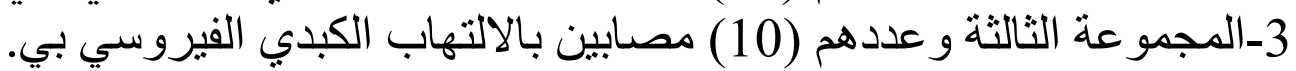

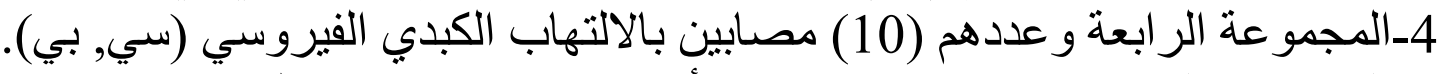

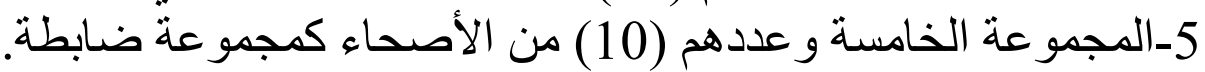

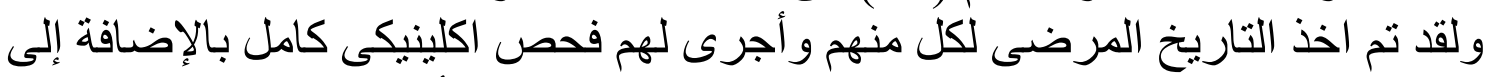

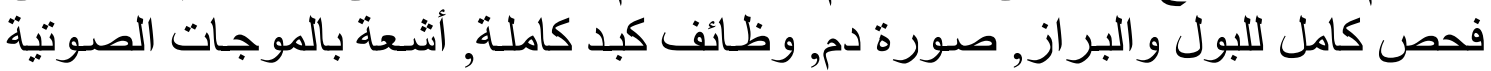

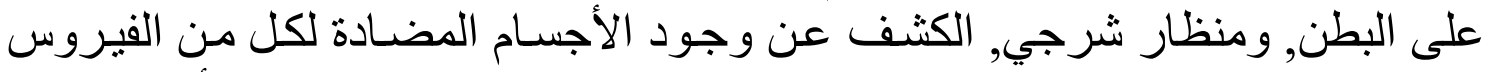

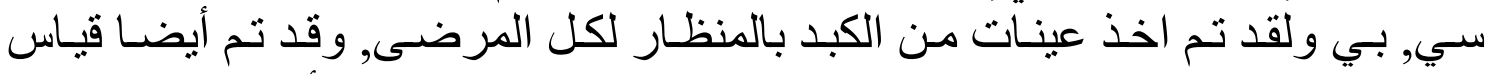

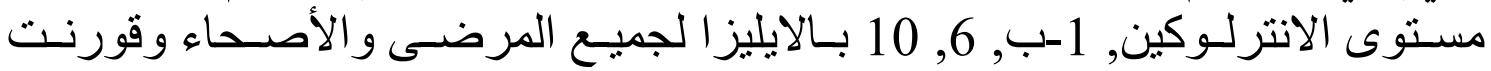
نتائجه بنتائج المجمو عة الضابطة.

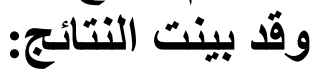

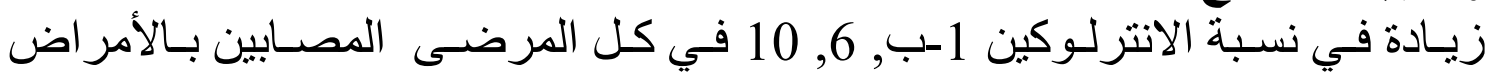

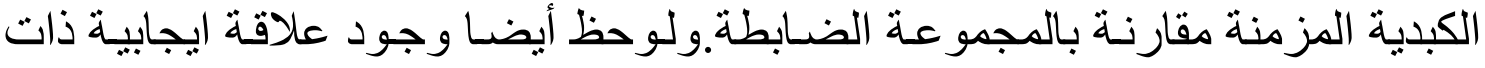

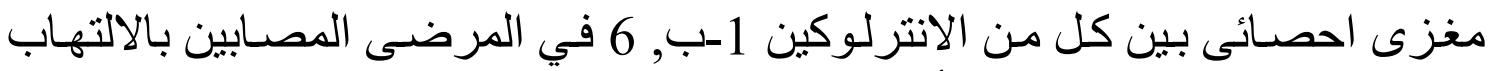

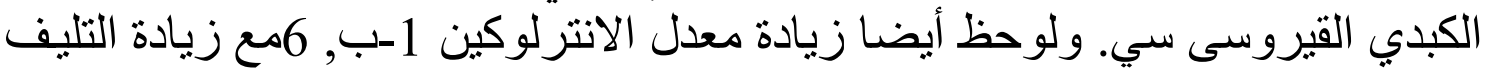

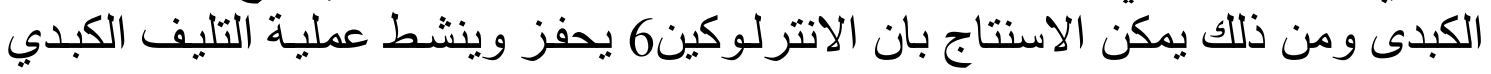

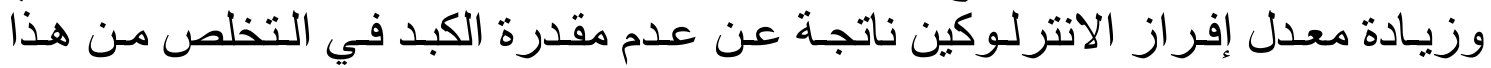

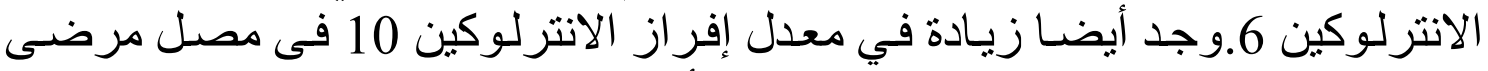

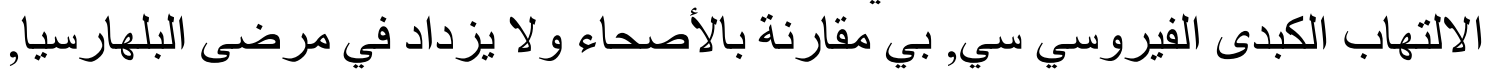

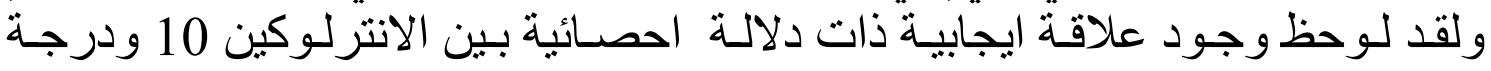

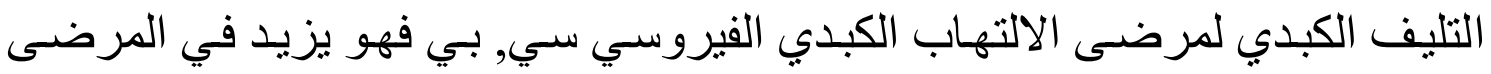

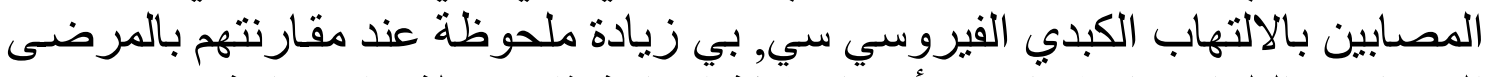

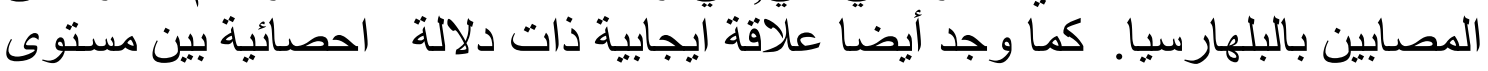

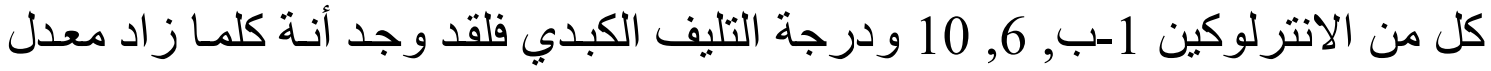

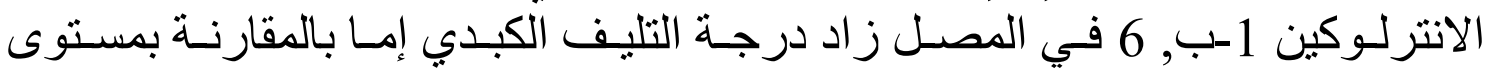

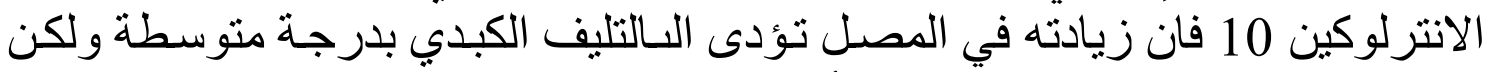

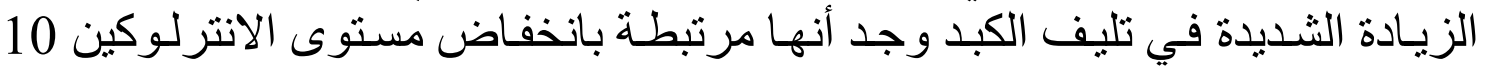

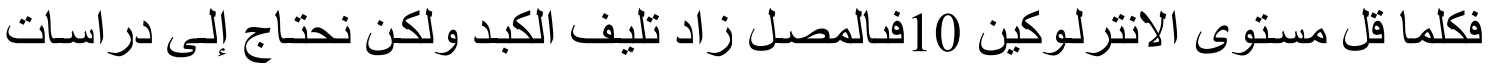


أخرى في هذا المجال بحيث تشمل عدد اكبر من المرضى و استخدام الانترلوكين 10 كعلاج للمرضى المصابين بالتليف الكبدالثديد ومدئ ونى فعاليتة كعلاج. 